\title{
Analysis on the Factors Influencing the Performance of Innovation and Entrepreneurship Education in Colleges and Universities
}

\author{
Fei Wang ${ }^{1, ~ a ~}$, Hailan Luo, b ${ }^{2,}$ Fuqing Wang ${ }^{2, c}$ and Jianguo Wang ${ }^{2, d}$ \\ ${ }^{1}$ Department of Food and Nutrition Luohe Key Laboratory of Medical Bioengineering Luohe \\ Medical College, Luohe, China \\ ${ }^{2}$ Luohe Key Laboratory of Medical Bioengineering, Luohe Medical College, Luohe, China \\ aawhovering@yahoo.com, ${ }^{b} x i a o h a i l u 01224 @ 163 . c o m,{ }^{c}$ wangfq22000@163.com, \\ dwr0395@sina.com
}

Keywords: Influence factors; Performance influence factors; College education innovation; Innovation of entrepreneurship education; Analysis

\begin{abstract}
The main factors which affect the performance of innovation and entrepreneurship education in colleges and universities are that the educational goals and philosophy of innovation and entrepreneurship is relatively narrow, the education resources are in a lack and teaching methods are outdated and old-fashioned. Therefore, the scientific positioning the innovation and entrepreneurship education in colleges and universities, strengthening the building of the entrepreneurial team of teachers, and constructing entrepreneurship education practice platform in colleges and universities are the important measures to improve the entrepreneurship innovation education performance of colleges and universities.
\end{abstract}

\section{Introduction}

The innovation of entrepreneurship education in colleges and universities is a new model and teaching idea which is to meet the needs of the development of social economy and national strategy. It has a great practical significance to improve the teaching quality of higher education and the quality of training personnel in our country. Therefore, how to effectively improve the innovation of entrepreneurship education in colleges and universities to achieve higher performance is particularly important. However, the innovation entrepreneurship education of colleges and universities in our country is limited to the number of College Students' education, who are the intention to start business after graduation, or join in the activities for the development of entrepreneurship competition. The limit makes the innovation entrepreneurship education in colleges and universities be in a situation that can be held or released, sometimes exist or not, while its performance is generally poor. This paper intends to analyze the specific factors that affect the improvement of the performance of the innovation of the entrepreneurship education in colleges and universities and gives the corresponding countermeasures.

\section{The Situation of Innovation and Entrepreneurship Education in Colleges and Universities in China at Present}

The entrepreneurship education in colleges and universities is a new concept in the United States as a new education. At present, the developed countries such as Europe and the United States attach great importance to the innovation and entrepreneurship education. They have formed a relatively complete theoretical system, which has entered a mature state. Comparing with the innovation and entrepreneurship education in the Europe and the United States, the idea of higher education should be first appeared in the "decision to continue education reform and promoting quality education". In 1998, the decision issued by National Education Ministry pointed out: the higher education must pay attention to cultivate college students' innovative ability, so that they have practical ability and entrepreneurial spirits, which could improve college students' humanist quality and scientific literacy. In 21 st century, with the domestic labor force and the increasing contradiction of the employment, as 
well as the difficulty in job searching of college graduates, the government and the Minister of Education pointed out on the 17th CPC National Congress that "to strengthen the concept of employment and education, so that more workers become innovative entrepreneurs ", "Innovating entrepreneurship, entrepreneurship to promote employment, so that more workers become entrepreneurs of innovation leader.'In response to the government's call, followed by a new trend of education development, the Central Committee held the first challenge cup national college students entrepreneurship program in 1999. In April 2002, the higher education department and the Renmin University of China in Beijing 9 colleges and universities held a forum for innovation and entrepreneurship and identified them as the pilot innovation and entrepreneurship education institutions, and these have become the government led by the diversified development stage of other institutions. From the present situation, the domestic colleges and universities put forward three kinds of typical college student innovation and entrepreneurship education model: the Renmin University of China as a representative of the subject oriented model; Shanghai Jiao Tong University as the representative of the integrated model. With the experience of the pilot schools, many institutions in China actively carry out innovation and entrepreneurship education in the new educational concept, and explore and research in the existing educational system, and strive to build a new model system of education teaching practice, the purpose is to improve the quality of College Students' entrepreneurship. Even colleges such as Luohe Medical College, built in the "Chinese wellknown city for its food", should follow the "Mass entrepreneurship and innovation" policy, to perform teaching reform aim at food industry. However, although the institutions of higher learning have become the leading of the innovation and entrepreneurship education in China, there are still many problems in the aspects of team research, platform practice, educational content and methods, management system and so on. These mainly reflected in: the lack of in-depth understanding the scale, model and curriculum design of innovation and entrepreneurship education, practice is not enough. Lack of professional education, quality education, innovative education, innovative spirit of entrepreneurs, the lack of innovative practice activities, the lack of macro environment and social support; lack of suitable for different types of schools to promote the implementation of teaching practice. These problems seriously restrict the development of science and technology innovation and entrepreneurship higher education in China.

\section{The Factors Affecting the Performance of Innovation and Entrepreneurship Education in Colleges and Universities}

The Concept and Target of Innovation Entrepreneurship Education of Colleges and Universities Is Relatively Backward. Because of the Ministry of Education vigorously promotes self-employment work of college students of innovation entrepreneurship education of colleges and universities of the government, the colleges and universities which develop innovation entrepreneurship education become more and more in the country. Although innovation entrepreneurship education of colleges and universities get more and more attention, the goals and ideals still have narrow understanding. The innovation entrepreneurship education and employment practices of the students of ethnic minorities tend to be the utilitarian commercial value judge. More entrepreneurial culture takes several independent "entrepreneurs" as the goal of innovation entrepreneurship education, which is really difficult to understand the intrinsic value of the talent training quality, so the teaching level of entrepreneurship education innovation education is not promoted, which will include personnel training plan. Meanwhile, innovation entrepreneurship education limits college students' horizons to do utilitarian value judgment, so that they will not according to their own entrepreneurship training and promotion of their characteristics vocational education, which leads them mistakenly think innovation entrepreneurship education can quickly bring economic benefits. The understanding to innovation entrepreneurship education of a new founder with low business level is only limited to earning money to feed the family. Taking innovation social entrepreneur spirits as the activities of innovation social value is conducive to solve the unsolved problems of the society. Market and the government shall help to create 
awareness of college students to serve the society. Entrepreneurs shall use the energy provided by market, which is to use market rules, to meet the demands of the society to promote the social value. Therefore, the narrow understanding of the concept and target of innovation entrepreneurship education and the influence of innovation entrepreneur spirit which is to improve the quality of education are the reasons that the performance of innovative entrepreneurship education of colleges and universities is hard to improve.

Lack of High Quality Innovation and Entrepreneurship Education Resources. The improvement of the spirits of innovation and entrepreneurship needs the support of financial resources and human resources. However, the colleges and universities which are in a lack of innovation and entrepreneurship education resources will be difficult to promote innovation and entrepreneurship education to all students. It can not be integrated into the whole process of personnel training, the reasons of which are, firstly, schools haven't set up specialized agencies for special funds or workplace for the implementation of innovation and entrepreneurship education, and many colleges and universities add the content in the office of student affairs, which makes the funds which can be used for entrepreneurship education are often stretched or be used in other places; secondly, the innovation and entrepreneurship education in colleges and universities should have the professional background of the economic management personnel. The shortage of teacher resources in this area directly impacts the development of innovation and entrepreneurship education.

Methods on Innovation and Entrepreneurship Education in Colleges and Universities Are Old-fashioned. The main purpose of the entrepreneurship courses is to make the students get the innovative method, and realize the essence of innovation. To become an effective business accumulation, entrepreneurship education needs to make students understand the knowledge with innovative content by heuristic education, inquiry learning, discussing education, as well as experiential teaching methods, not being applied to the classroom or work. Students can improve their abilities to solve problems in the case of uncertainty and unpredictable. However, the "spoon feeding" teaching method and the optimized difficultly classroom teaching always make students lose the way to solve problems in the analysis of problems of uncertainty. Therefore, a new concept of innovation and entrepreneurship education is to change this situation, in order to help students improve the ability to solve problems, which requires students to actively participate in the learning process, rather than passively receive the knowledge and information. There is no doubt that if we want to achieve the desired learning outcomes, it is necessary to accord to the teaching content, and to choose the most suitable teaching method, to arouse students' subjective initiative, and to make students can experience entrepreneurs work method, experience in future business may experience in a variety of situations and to have the ability of active knowledge mining, with the method of research and application of knowledge, to enter the society bear good lay a solid foundation on "the role of entrepreneurs". Thus, the old teaching methods will hinder innovation and entrepreneurship education and reduce the ability of colleges and universities.

\section{The Countermeasures to Improve the Performance of the Innovation Entrepreneurship Ducation of Higher Education}

Positioning of Innovative Entrepreneurship Education in Colleges and Universities Shall Be More Scientific. As the essence of innovation entrepreneurship education in colleges and universities, "education" is also the new situation of the quality-oriented education which has developed to the current stage. Therefore, people-oriented thought has very important practical significance to innovation entrepreneurship education in colleges and universities, which is beneficial to the cultivation of student's beliefs, is an important precondition to improve students' comprehensive competition and can promote the all-round development of students. Education gradually combines with innovation entrepreneurial education. The goal of innovation entrepreneurial education is included in the scope of the quality education, and expands to each college by the "integration" process of education, management and education service, and connects 
to ideological and political education, vocational education and research, social services and cultural inheritance. Since entrepreneurship education is integrative innovation, creation and cooperation, and has the courage to take risks. It has valuable ability to cultivate and develop of interdisciplinary talents in these fields. In fact, not only business school students, but also the students of other schools and even of high school, are interested in being engaged in entrepreneurship activities. Some of these students may grow up to become successful entrepreneurs. The entrepreneurship spirits of colleges and universities are not to cultivate students to become founders. However, the students who are experience entrepreneurship "influence" will be able to promote the updating concept of innovation entrepreneurship education when they entering the traditional industries of these fields.

To Strengthen the Construction of Teaching Staff so as to Promote the Innovation Entrepreneurship Education in Colleges and Universities. To strengthen the construction of teachers of innovative entrepreneurship education, the key is to facilitate the implementation of the curriculum system of innovation entrepreneurial education. Entrepreneurship education is a practical course, in addition to the teacher with rich theoretical knowledge, it is more important to have the real practical experience, which requires teachers in colleges and universities must have the double qualities of "scholars and entrepreneurs". Entrepreneurship practice experience can give instructive guidance for college students when they undertaking entrepreneurship. We should take cultivating the teachers with "double types" as the point of the construction of teaching staff. Employ the experienced talents with "double quality" which are production and management as the teachers of entrepreneurship education. Therefore, to strengthen the construction of teaching staff of innovation entrepreneurship education, it is necessary to actively guide the professional teachers of innovation entrepreneurship education and to carry out employment and entrepreneurship, innovation theory and case study. Innovation entrepreneurship education shall be effectively listed into the professional education and culture quality education; what's more, it is necessary to support teacher's credential exercise to enterprises, to encourage teachers to participate in social practice activities of innovation and entrepreneurship to gain experience of all aspects; in addition, it is also important to actively invite successful entrepreneurs experts and scholars from all walks of the society to act as part-time teachers and to recruit entrepreneurs, so as to establish a special combination of entrepreneurship education teachers with high quality. Finally, it is needed to organize regular teacher training to constantly improve the scientific research level of teaching, innovation and entrepreneurship of teachers to guide students to practice.

Build a Practice Platform to Promote the Innovation Entrepreneurship Education of Colleges and Universities. The characteristics of innovation entrepreneurship education practice and the decision of colleges and universities entrepreneurship education must be extended to the business practice of business platform and help students to hone the will, accumulate experience and improve employment ability through the necessary practical problems. First of all, to establish innovation education school entrepreneurship practice platform. On the one hand, in innovation entrepreneurial education teaching practice, graduation design paper, expand the quality of the combination of the second classroom of education. On the other hand, to establish business incubator park to create a comprehensive business support platform for college students and to provide the necessary material assistance of their business practices, to actively integrate "university - enterprise - business students" and other excellent resources in all aspects, as well as "college students business street", "college students business groups" and other management, and to establish working environment which is conducive for the policy measures and incentive measures which are carried out by entrepreneurship. In the process of operation, the entrepreneurial base shall provide some supports from site, funding, training, technical supports. The mature start-ups entrepreneurial projects create opportunities to promote its market and to become a real enterprise. At the same time, to establish innovative entrepreneurship education service website, strengthen the exchange of business information, provide policy advice, and promote good business opportunities, excellent and alumni tracking service and entrepreneurship training. The second is to carry out outdoor training to the practice base of the innovation entrepreneurship education of colleges and 
universities. This is the usual commercial practice to expand base and to establish social practice service platform, which makes students of the main campus can intuitively understand enterprise and entrepreneurship. In order to encourage entrepreneurship, and is willing to help students to contact with the society as much as possible after school or on holidays under the condition that the social activities will not affect their learning situation. Establish and attend some entrepreneurial projects with small investment, quick effect and low risk, increasing the innovative and entrepreneurship abilities of students in practice.

\section{Conclusion}

To sum up, to improve the performance of the innovation and entrepreneurship education of colleges and universities, a more effective running mechanism is needed to design, in order to realize the encourage compatible and efficient allocation of entrepreneurship education resources of participants, and fusion the individual goal of participants and the innovation target of the entrepreneurship education of colleges and universities, to promote and integrate resources and to use them into the innovation activities of entrepreneurship education. Only positioning the ideal and goal of entrepreneurial innovation education of colleges and universities with more scientific attitude, increasing the resource supply of the innovation entrepreneurship education of colleges and universities, strengthening the teachers team construction of entrepreneurship, focusing on the innovation of teaching methods and constructing the entrepreneurial practice education platform can significantly improve the performance of the entrepreneurial innovation education of colleges and universities in our country.

\section{Acknowledgements}

This work was supported by the Entrepreneurship Training Demonstration Base Construction Project of Henan Province.

\section{References}

[1] Wang Wei. Study of the impacting factors of the performance of innovation education and entrepreneurship education of colleges and universities [J]. Education Comments, 2015,08:86$87+156$.

[2] Wang Yunbo, Sun Yingjuan, Jing Hongjun. Research of Innovation and entrepreneurship education system of colleges and universities [J]. Century Bridge, 2015,03:65-67.

[3] Zhang Tianhua, Wang Xulong. Study of the teaching resources development of innovation and entrepreneurship education of colleges and universities [J]. Journal of Liaoning University of Technology (Social science edition), 2015,04:75-78.

[4] Bai Yun. Study of the practice of innovation and entrepreneurship education of colleges and universities [J]. The Chinese and foreign entrepreneurs, 2015,21:168.

[5] $\mathrm{Yu}$ Wen. Study of the present situation and the countermeasures of innovation and entrepreneurship education of colleges and universities [J]. The road to success, 2015,19:10-11.

[6] Cao Yang. Research of the problems of innovation and entrepreneurship education of colleges and universities under the background of the transformation of the mode of economic development [D], Northeast Normal University, 2014.

[7] Chen Liang. Study of the support of ideological education work to the innovation entrepreneurship education of colleges and universities- Taking Nantong University as an example[J]. Horizon of science and technology, 2014,08:134+152. 
[8] Wang Chengguo. Study of the present situation and the countermeasures of innovation and entrepreneurship education of private higher learning institutions [J]. Heilongjiang Local Chronicles, 2013,23:289.

[9] Chen Jingliang. Innovation and entrepreneurship education [M]. Fudan university press, 2012: 125-129.

[10]Ni Feng. Overview of innovation and entrepreneurship education [M]. Higher education press, $2012: 145$. 